\title{
Between Regulation and Minority Educational Rights: Secularism and the Indian Supreme Court
}

Secularism is seen as a central value that underlies the Indian constitution. The preamble to the constitution affirms India's status as a secular State. ${ }^{1}$ The Indian Supreme Court has argued that secularism is part of the 'basic structure of the constitution'. ${ }^{2}$ At the same time, the Indian constitution is also celebrated by political theorists for its safeguards for religious minorities in the sphere of education. ${ }^{3}$ It guarantees that such minorities shall have the right to establish and administer educational institutions of their choice [Article 30(1)]. It also guarantees that the State shall not, in granting financial aid, discriminate against any educational institution on the ground that it is under the management of a minority [Article 30(2)]. ${ }^{4}$ These provisions are hailed as instituting a regime of cultural rights that take cognizance of the claims of groups rather than merely of individuals.

These constitutional provisions, however, have faced considerable criticism from Hindu nationalists in India, who see them as unfair concessions to minorities. The Bharatiya Janta Party and its allies have repeatedly criticized the rights guaranteed to religious minorities by Article $30 .^{5}$ They have argued that religious minority educational institutions should not be exempted from the regulatory power of the State since this practice violates the ideal of secularism. Any theoretical response to their challenge must explain how a constitution that values secularism can also guarantee rights specifically to religious minorities. It must explain which version of secularism is in operation in India's jurisprudence on minority educational rights.

While one might wish to provide an account of secularism that shields minority educational rights from the Hindu right, one must confront another debate recently opened up by litigation in relation to the Right to Education Act (RTE). This legislation required that all private schools must admit students from 'Economically Weak Sections' against $25 \%$ of their total available places. It was underpinned by the idea that private schools, where a third of India's students are enrolled, must play their part in order to ensure universal access to education. Schools managed by religious and linguistic minorities, all of which are private - some even aided by the State- have 
argued that the RTE could not apply to them since they were protected by Article 30 of the Indian constitution. In a 2014 judgment, the Supreme Court sided with these schools and ruled that the RTE was invalid in its application to aided as well as unaided minority schools. ${ }^{6}$ Critics of the judgment argued that, in its complete deference to minorities' claims, the Court had unfairly overlooked the interests of economically disadvantaged students. ${ }^{7}$

Is it possible to provide an account of secularism that permits rights specifically for religious minorities, while, at the same time, allowing for these to be qualified in ways that do not undermine legislation like the RTE? In this article, I argue that there is indeed a conception of secularism that responds to this dual challenge. I suggest that Rajeev Bhargava's notion of principled distance best captures the operation of secularism in the debate over minority educational rights in India. I then demonstrate that this conception possesses the conceptual resources to defend rights for minority educational institutions while qualifying these insofar as other interests - such as those relating to the RTE—are concerned.

The debate over minority educational rights is, in some ways, distinctive in relation to other debates on secularism and group-differentiated rights in India. Separate family laws based on religious norms, for instance, have been subject to considerable political controversy, inviting legislative intervention by the Rajiv Gandhi government in 1986. Similarly, affirmative action for 'Scheduled Castes', 'Scheduled Tribes' and 'Other Backward Classes' has been an issue that has been mobilized by electoral players and other political actors. On the contrary, the minority educational rights debate has largely been restricted to judicial chambers, with almost no legislation on the subject. As such, the scope of these rights has been delineated almost entirely by a series of judgments by the Supreme Court. Indeed, separate personal laws and affirmative action have also reached the Court's chambers, but this has gone alongside legislative intervention specifically on these issues. Further, although minority educational rights have been the subject of criticism by the Hindu-right, they have rarely invited the kind of electoral mobilization witnessed by debates over family law or caste-based affirmative action. ${ }^{8}$ As far as judicial debates go, the scope of minority educational rights constitutes 'one of the most litigated areas of constitutional law' in India. ${ }^{9}$ Yet the Court's response to this debate has been confusing to say the least. ${ }^{10}$ By suggesting that the Indian Supreme 
Court's response is one best described as one of principled distance, I also hope to help make better sense of its seemingly chaotic jurisprudence.

It is worth noting that the debate over RTE and minority educational institutions can also be seen as part of a larger theoretical debate over the legitimate scope of the rights of religious groups, particularly minorities, in relation to the State's regulatory role in education. This debate has occurred in various forms in several jurisdictions. As I later argue, the two central questions in the constitutional debate in India have been over the State's regulatory role in relation to the choice of students, and the selection and regulation of employees in religious minority institutions. These questions have been raised elsewhere, as when the Faith School District in South Dakota, United States, terminated a teacher's contract for responding to students' questions about homosexuality ${ }^{11}$; or when a Jewish Faith School's policy of preferential admission to members of the religion was questioned in the United Kingdom. ${ }^{12}$ This article demonstrates how the Indian Supreme Court has responded to such questions. Examining the theoretical conception which underpins this response ought to be of interest to those interested in the tension between multiculturalism and the State's regulation of education beyond India.

In the first section, I begin by describing Bhargava's approach, and contrasting this with two alternative conceptions of secularism. The second section provides a brief overview of the constitutional provisions on minority educational rights in India and the ambiguity surrounding the institutions these cover. In the third section, I discuss the legal debates on minority educational rights across landmark cases of the Indian Supreme Court. The fourth section discusses why principled distance better accounts for the Court's approach to these debates relative to competing accounts of secularism. The fifth section then emphasizes a second dimension to the Court's engagement with this debate: the relationship between private enterprise and education. In the sixth section, I demonstrate how principled distance allows us to address the controversy surrounding the application of RTE to minority schools.

\section{Political Secularism: Exclusivist, Lexically-Ordered, and Principled Distance}


Rajeev Bhargava argues that India's constitutional and political practice can be understood in terms of a 'principled distance' model of secularism. He suggests that separation between religion and the State can occur at three distinct levels. ${ }^{13}$ First, there might be separation between the two at the level of ends or purposes. Secular States define their ends in terms of principles like justice, equality and liberty, rather than, say, salvation, the or the truth of religious doctrines. Second, religion and the State might be disconnected at the level of institutions. Such separation entails there is no mandatory or presumed presence of religious personnel in the structures of a State. No part of the State's power is automatically made available to members of religious institutions. Third, religion and the State might be separated at the level of policy. This includes things like the State's norms about not permitting religious instruction in schools, not giving funding for denominational institutions or insisting on the application of its laws and procedures governing familial ties, and its approach towards religious or communal laws and norms regarding, for instance, divorce.

Bhargava argues that the dominant understanding of secularism is that this third-level disconnection is crucial. ${ }^{14}$ However, secularism can also involve disconnection between religion and the State at the level of ends and institutions, while allowing a particularist approach to this relationship at the level of policy. The Indian approach to secularism allows for such a relationship of principled distance. ${ }^{15}$ This approach allows the State to engage with claims of religion, for instance, by allowing distinctive treatment for minorities on a range of grounds. On the other hand, it also permits State intervention and regulation of religious groups' practices when this is required. The precise relationship between religion and the State demanded by principled distance is a matter of context rather than any well-delineated rule:

It (secularism) requires fresh interpretations, contextual judgments, and attempts at reconciliation. No general a priori rule of resolving these conflicts exist; no easy lexical order, no pre-existing hierarchy among values or laws that enables us to decide that, no matter what the context, a particular value must override everything else. Almost everything then is a matter of situational thinking and contextual reasoning...the practice of secularism requires a different model of moral reasoning than the one that straitjackets our model of moral understanding in the form of well delineated explicitly stated rules. ${ }^{16}$ 
Further, this absence of a well-delineated rule means that the State's response to religion must attempt to reconcile various competing values and interests at stake in particular circumstances:

\begin{abstract}
This endeavour to make concepts, viewpoints, and values work simultaneously does not amount to a morally objectionable compromise. Nothing of importance is being given up for the sake of a less significant thing, one without value or even with negative value. Rather, what is pursued is a mutually agreed middle way that combines elements from two or more equally valuable entities. ${ }^{17}$
\end{abstract}

I shall argue that this conception of secularism best captures the operation of minority educational rights in India. Before defending this claim, I wish to emphasise the scope of my argument. Conceptual analyses like Bhargava's attempt to capture the way the State engages with religion, assuming that there is a homogeneity in such a relationship across various domains. Instead, it might be that the State's approach to religious minorities in the sphere of education differs from, say, that in the domain of laws on marriage. I argue that Bhargava's conceptual analysis helps understand a particular practice of secularism in India, leaving open the question of whether this analysis has purchase outside the domain of minority educational rights.

Bhargava's 'principled distance' approach to secularism can be contrasted with two others. An exclusivist conception of secularism involves erecting a wall of separation between religion and the State, such that the State must have nothing to do with religion. The State is separated from religion (a) not only in defining its ends or basic principles in a non-religious manner, (b) not only in declining to recognise a church or some religion as the official one, but also (c) by rejecting any engagement with religion in matters of policy. ${ }^{18}$ Examples of areas of policy where exclusivist secularism may be applied include prayers in governmental organisations, State-funding for religious schools, and the presence of religious symbols in educational institutions.

Alternatively, one might understand secularism in India as lexically ordered engagement between religion and the state. Bilgrami argues that secularism, properly understood requires that 'if and when there is an inconsistency that arises between certain goals sought to be achieved in a polity that are formulated independently of religion, and the practices of a religion, the former must be placed first and the latter 
second'. ${ }^{19}$ This approach allows for engagement with religion, and even distinctive treatment for minorities, when this is warranted by values to which the State subscribes. For instance, the State's commitment to the principle of equality can allow it to provide certain cultural rights to religious minority groups in the interests of substantive equality with the majority community. However, the lexically ordered approach insists that this engagement must be subordinated when it is inconsistent with other ideals that the State wishes to achieve. These ideals are often, though not always, 'enshrined in stated fundamental rights and other constitutional commitments'. ${ }^{20}$ Thus, the 'lexical ordering' in Bilgrami's approach refers to the subordination of claims to free exercise of religion, which must be trumped by other constitutional ideals and rights.

The lexically ordered conception differs from exclusivist secularism, which insists that the State must disengage from religion under all circumstances. Against this, Bilgrami's approach urges that the State may engage with religion insofar as this is compatible with its own values. Disengagement is necessary only when such values would be contravened, for instance, when religious persons call for restrictions on blasphemy in a State that professes commitment to freedom of speech. ${ }^{21}$ But Bilgrami's approach also differs from Bhargava's which insists that there is 'no easy lexical order, no preexisting hierarchy among values or laws'. ${ }^{22}$ When the free exercise of religion clashes with other ideals to which a State subscribes, principled distance urges that we ought to make both values work simultaneously, combining elements from the two, rather than viewing the former as subordinate to the latter.

Proponents of both approaches exist in the theoretical literature on secularism beyond India. Scholars like Stephen Macedo and Jonathan Quong can be viewed as proponents of the exclusivist approach, since they aim at minimizing the influence of religion in the public sphere. ${ }^{23}$ They insist that liberal legitimacy requires the exclusion of religion from any deliberation upon public policy. On the other hand, several liberal multiculturalists adopt what Bilgrami calls a lexically ordered conception of secularism. They allow for engagement with claims by religious groups, particularly those of disadvantaged minorities. Such engagement, however, subordinates any acceptance of those claims to liberal values, such as the protection of individual freedom, as in the case of feminist commentators like Susan Okin, and social justice, in the case of liberal egalitarians like Brian Barry. ${ }^{24}$ 
Both alternative conceptions examined here have been claimed as the appropriate one for describing the Indian case. T.N. Madan and Ashis Nandy view secularism in India as a form of exclusivism, which is hostile to the presence of religion in politics and attempts to eliminate it from the public sphere. ${ }^{25}$ Bilgrami, on the other hand, argues that his own approach to secularism as lexically ordered accounts for India's accommodation of religion subordinate to other values outlined, for instance, in the fundamental rights that the constitution guarantees. ${ }^{26}$ His suggestion finds support in Jacobsohn's description of the religion/State relationship as 'ameliorative secularism': where the State is not prevented from intervening in matters of religion to promote social welfare. ${ }^{27} \mathrm{He}$ argues that the Supreme Court's jurisprudence 'has been to frequently curtail free exercise (of religion) rights in the name of social justice' ${ }^{28}$ In other words, an ideal like justice stands lexically superior to free exercise of religion in the Indian judiciary's understanding of secularism. Before I demonstrate why Bhargava's approach captures the jurisprudence on minority educational rights in India better than either of these alternatives, it is worth investigating the legal framework with respect to such rights, and the kind of institutions that have claimed their protection.

\section{Minority Educational Institutions: The Legal Framework}

The partition of British India into India and Pakistan was accompanied by a mass transfer of populations. Several millions were uprooted and transformed into official refugees, as violent communal strife killed an estimated five hundred thousand people. ${ }^{29}$ It was against this political background that the Constituent Assembly deliberated upon the framing of India's constitution and questions relating to the rights of religious minorities between 1947 and 1949, with Muslims forming the largest minority group.

Rochana Bajpai's pioneering study on the treatment of minority rights in India's Constituent Assembly demonstrates that concern for national unity dominated debates during the drafting of the constitution, leading to hostility towards the notion of separate rights for minorities. ${ }^{30}$ It was argued that communal electorates were responsible for sowing the seeds of partition and, therefore, any move to differentiate citizens on the 
basis of religious identity would be detrimental to the development of a united nation. The only exception to this trend was Article 30, the first provision of which states that '[a]ll minorities, whether based on religion or language, shall have the right to establish and administer educational institutions of their choice'. The second provision of this Article adds that ' $[\mathrm{t}]$ he State shall not, in granting aid to educational institutions, discriminate against any educational institution on the ground that it is under the management of a minority, whether based on religion or language'. Shefali Jha argues that this was forwarded as part of a compromise according to which religious minorities would no longer need political safeguards in the form of legislative quotas since their cultural and educational rights were guaranteed by the constitution. ${ }^{31}$

In the absence of any legislation delineating the scope of minority educational rights in India, the jurisprudence on this subject has come entirely from a series of landmark judgments of the Indian Supreme Court: the Kerala Education Bill Case (1958), the Xavier's Case (1974), the Stephen's Case (1992) and the Pai Case (2002). ${ }^{32}$ The paradigmatic status of these judgments lies in the Supreme Court's own reference to these as constituting the central basis for its jurisprudence on the subject. ${ }^{33}$ Although these cases constitute authoritative sources of the Court's jurisprudence, its stance on the matter has been further upheld in a series of subsequent judgments of the Supreme Court and various High Courts. Since this article focuses on the Court's legal position on minority educational rights, it is appropriate to turn to these landmark cases, while keeping in mind that its decisions in these has been applied to a wider range of cases.

In all of the landmark cases, minority educational institutions contested regulations made by the Government, or officials in universities to which such institutions were affiliated. These regulations pertained to matters like the admission of students, selection of employees and regulation of their service conditions. In the Kerala Education Bill Case, these changes were undertaken by a legislative act that gave power to the government to prescribe teachers' salaries, qualifications and service conditions. It also empowered the state's Public Service Commission to determine which teachers were eligible to teach in service conditions. In Xavier's, such changes were undertaken by means of legislation in the State of Gujarat that empowered the officials of the University to participate in the selection of teachers, withhold approval to disciplinary action against employees and take over teaching for undergraduate courses in all 
colleges, including those run by religious minorities. These changes were opposed by St. Xavier's College, a Christian minority educational institution affiliated with the University, as well as other minority educational institutions which are not named in the judgment. In both cases, therefore, the clash with minority educational rights emerged from an attempt by the State to exercise greater control in the sphere of education - a domain that also included minority institutions. In the Stephen's Case, the conflict was a result of the State's attempt to ensure that minority educational institutions complied with existing rules that applied to other institutions. In this case, St. Stephen's College's policy of preferential admission for Christian students was opposed by the University of Delhi, to which it was affiliated. The University also opposed the college's policy of interviewing candidates rather than admitting students exclusively on the basis of school-leaving examinations - the method followed by all other colleges affiliated to the University.

The Pai Case differs not just from those outlined above, but also from most cases before the Indian Supreme Court. It was heard by a constitution bench of eleven judges - an event which had occurred only once before in the Court's history. Here, the judges were not responding to a particular case or situation, but to a set of questions framed by a lower bench of the Supreme Court about principles involved in minority educational rights. The judgment in the Pai Case states that the Supreme Court was approached by the Islamic Academy of Education in 1993, which had raised questions pertaining to the scope of minority rights under Article 30(1) of the constitution. The Islamic Academy's petition was joined with several other connected petitions and placed before a bench of five judges, which in turn ruled that the above petitions raised questions of constitutional significance that would need to be addressed by a larger bench of seven judges. The seven-judge bench forwarded the questions received by the five-judge bench to a larger bench of eleven judges. More than 200 petitions by several stakeholders-including minority as well as non-minority educational institutionswere included in the hearing on this case. ${ }^{34}$ Thus, the Court in the Pai Case was not responding to particular regulatory moves and their constitutionality, but was asked to lay down principles that would guide decisions in particular cases.

In the next section, I examine the claims made by minority educational institutions regarding Article 30 in these landmark cases, and outline the Court's response to these. 
In Section 5, I discuss how Bhargava's conception of political secularism as principled distance best accounts for the Court's stance on minority educational rights. Before proceeding, it is worth examining the nebulousness around the term, "minority educational institutions'. Educational institutions in India operate at either of three levels: schools, colleges or professional colleges. Such institutions could be State-runadministered by the Central or State government — or private. Private educational institutions may be either aided or unaided. Aided private educational institutions receive, to varying degrees, financial assistance from the State. In some instances, such aid is enough to cover almost the entire administrative cost of running the institution. All schools in India must adhere to norms prescribed by the State's relevant regulatory authority in matters like curricular requirements, examinations and minimum qualifications for teachers. In general, State-run/non-minority/aided institutions are subject to greater regulation by such norms than their private/minority/unaided counterparts. However, which of these dimensions allows the State to enforce greater regulation remains a matter of considerable controversy.

Private educational institutions must be established as charitable institutions in the sense that all surplus profits must be invested back in the institution itself. ${ }^{35}$ The management of private educational institutions consists of a governing body which is ordinarily responsible for the administrative affairs of that institution. All such administrative matters that are not defined by affiliating agencies lie within the ambit of the governing body, which may choose to delegate them, for instance, to the Principal of their institution. The governing bodies of different institutions vary in their composition. While some might give some representation to teachers or religious bodies, the average governing body consists merely of a set of individuals who have, together, established an educational institution, and may add further members by vote. In several cases, individuals administer educational institutions with governing bodies existing only 'on paper'. ${ }^{36}$

Within private educational institutions, there are some which claim that they are religious or linguistic 'minority educational institutions', and demand certain rightsdiscussed later in this article-under Article 30. Since this article is concerned with the former, I now examine which kind of institutions refer to themselves as such. First, 
there is no necessary connection between minority educational institutions and the religious community such institutions purportedly represent. While some minority educational institutions are affiliated with a religious organisation and contain its representatives in their governing bodies, this is not always the case. Second, even the relationship between a religious minority educational institution and the religious identity of its student body is not entirely straightforward. There are some minority educational institutions where almost a majority of students belong to that particular minority community. However, there are also minority educational institutions where students of the minority community make up a very small fraction of the total student population. Third, one must not assume that that the education of a religious minority educational institution must have a religious character. As mentioned previously, all recognised private educational institutions-including those that claim minority status - are affiliated to the relevant regulatory body, as a result of which the curriculum that they follow is a secular one. Thus, minority educational institutions are not institutions where the sole, or even primary, purpose is imparting religious education. While some of them might impart religious instruction, this cannot be compulsory for students, unlike the secular education that they impart. ${ }^{37}$ Finally, there is considerable debate over what counts as a 'minority educational institution' since different agencies of the state have adopted varying criteria. ${ }^{38}$

To sum up, it is necessary to approach the term 'minority educational institution' with caution, recognising the diversity of institutions it covers and the vagueness of criteria for its application. At the same time, it is important to keep in mind that regardless of their other features, such institutions are privately established and administered institutions. The Indian State does not manage any educational institutions with any religious affiliation, though it can provide funds to such organisations. Minority schools, then, are private organisations affiliated with the State's regulatory body such as the Central Board for Secondary Education. Minority colleges, similarly, are private institutions affiliated with the University Grants Commission, the State's official regulatory authority in higher education. Further, it is also worth reiterating that all minority institutions, like other private organisations, must comply with the curricular requirements established by the State's regulatory authorities. 


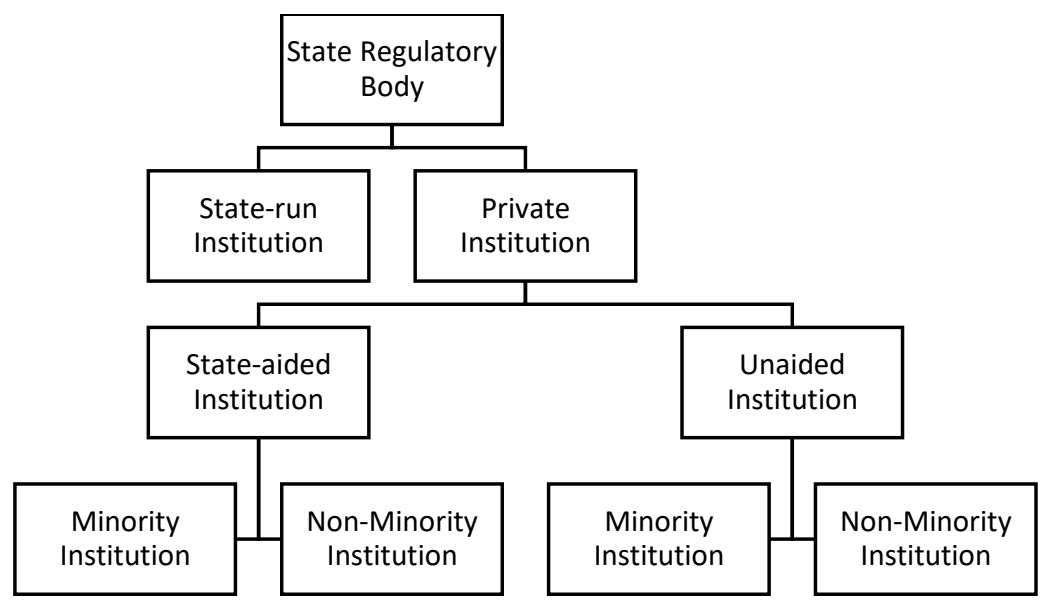

\section{The Debate over Minority Educational Rights in India}

Legal debates over minority educational rights in India have focused largely on two sets of questions: those relating to the selection of students, and those connected with the selection and regulation of employees. Later in this section, I shall briefly highlight what has been left uncontested by these debates.

The first set of claims in the debate over minority educational rights focused on the process of selecting students. This involved two distinct questions: first, whether a minority educational institution could be allowed to follow its own admission programme, rather than conforming to its University's norms; second, whether aided minority educational institutions could give preference to students from their own community during the course of admissions. ${ }^{39}$ The Court affirmed the former right, allowing minority educational institutions to adopt their preferred procedures for admitting students as long as these were limited strictly to testing academic merit. All other educational institutions would have to continue to follow the procedures prescribed by the State. ${ }^{40}$ I return to the Court's stance on this in Section 5(B).

The Court's response to the second question was more complex. Minority educational institutions' claim to preferentially admit students clashed with the constitution's nondiscrimination clause. While the former argued that they could reserve all places for students from their community, the State argued that the non-discrimination clause precluded them from reserving any places at all. The Court argued that there was a clash between Articles 29(2) and 30(1), which necessitated a balance between these 
provisions. It held that minorities had a right to admit their students preferentially, but would also have to leave a certain proportion of places open to all others. ${ }^{41}$ In the Stephen's Case, it initially held that no more than half the places could be reserved for preferential admission. However, in the Pai Case, it overruled this and held that no such fixed ceiling would be applied. Rather, governments in each Indian state could stipulate the upper-limit based on a range of local factors like academic needs. ${ }^{42}$

A second set of claims in this debate focused on the process of selecting employees and regulating their conditions of service. Minority educational institutions opposed provisions allowing for the participation of representatives of the State in procedures for selecting teachers, as well as initiating disciplinary action against them. The Court exempted minority institutions from such intervention, while allowing their application to others. It found that such regulations prevented minorities from imparting education consistent with their distinctive ethos and values. At the same time, the Court has repeatedly insisted that the autonomy available to minority educational institutions is not absolute. For instance, it accepted the State's right to prescribe minimum qualifications for teachers. ${ }^{43}$ Similarly, it has conceded that the State may hold disciplinary proceedings against employees to standards of fairness. ${ }^{44}$ In doing so, it has insisted upon the principle that even the autonomy of minority educational institutions can be regulated by reference to values like academic excellence or interests of teachers.

Thus, the Court's stance was, first, that regulation of minority educational institutions was permissible in the pursuit of interests like academic excellence; on the other hand, it also urged that any regulation which encroached upon the minority character of minority educational institutions was impermissible. This approach resulted in a somewhat indeterminate doctrine, as highlighted by Justice Hameedullah Beg in his dissenting opinion in Xavier's. He argued that standards of education — which the State was legitimately permitted to regulate — could not be separated from other aspects of administration where minority institutions wanted to retain their distinctive ethos. Indeed, the Court in Xavier's was aware of the difficulty in ensuring academic excellence while protecting the minority character of educational institutions. As such, it insisted on a contextual approach that weighed the interests of minorities against competing social and individual interests in every case. 

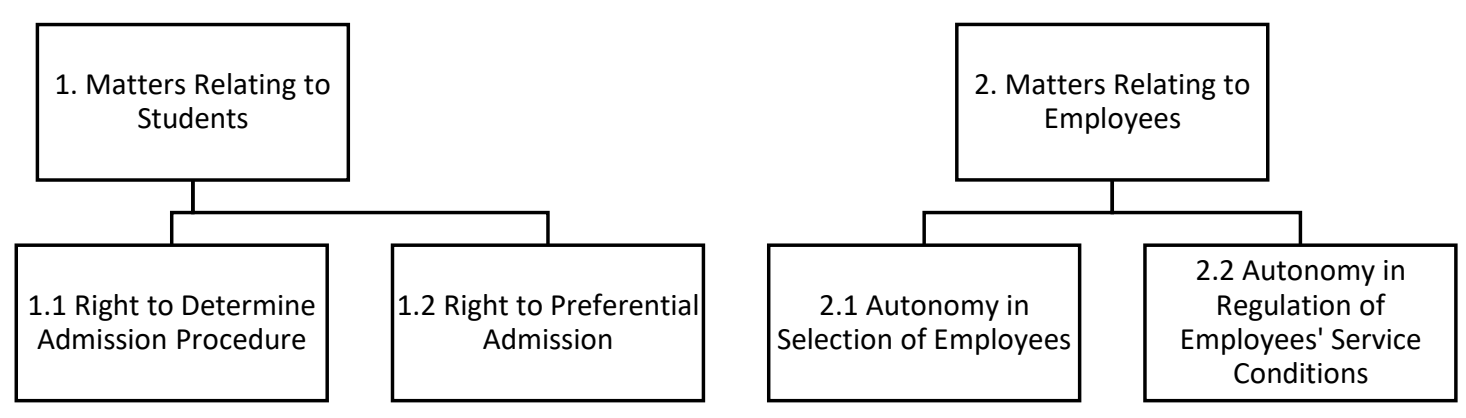

On what grounds has the Court has viewed the minority status of an educational institution as reason to afford it greater leeway than that given to non-minority institutions? Such autonomy is not defended, like in the United States, on grounds of a 'two-worlds theory'. As Jean Cohen argues, the American Supreme Court's recent jurisprudence is underpinned by the notion of distinct jurisdictional domains divided between two autonomous corporate bodies and sovereigns-Church and the State. ${ }^{45}$ This theory insists on prioritizing corporate religious autonomy, conferring jurisdictional authority on religious organizations allowing them to discriminate on the basis of a range of criteria.

This is not, however, the theoretical basis for the autonomy of minority educational institutions affirmed by the Indian Supreme Court. Such autonomy has been defended as necessary for protecting the 'minority character' of minority educational institutions. In other words, such institutions must be able to offer education consistent with the minority community's ethos, as distinct from the wider social ethos, where the majority's culture may be dominant. In the Kerala Education Bill Case, for instance, it stated that the constitutional guarantee under Article 30 was grounded in recognition of the legitimacy of minorities' claim that 'education should be imparted to the children of their community in an atmosphere congenial to the growth of their culture' ${ }^{46}$ Similarly, in Xavier's, the transfer of teaching to the University was struck down as unconstitutional since it would destroy the 'minority character' of minority educational 
institutions. ${ }^{47}$ Thus, the Court has insisted that departures from formal equality between minority and non-minority institutions were necessary in order to establish substantive equality between the two. Take, for instance, the permission given to minority educational institutions to preferentially admit students from their community. The argument works as follows: it is true that the State must treat religion and non-religion in an evenhanded manner. But religious minorities are placed at a disadvantage in managing their own institutions. Unlike an ordinary public institution, which will automatically see the large presence of non-minority students and teachers, minority institutions cannot do so unless special provisions are made for them. ${ }^{48}$ As a result, the attempt to overcome their disadvantage qua numerical minority ought to be understood as an attempt to approximate rather than violate equality. ${ }^{49}$ This equality is crucial in enabling religious minorities to protect and transmit aspects of their culture to students from their community.

Also worth noting here is what has been left uncontested in these debates. Even though questions over the relationship between minority educational rights and their relationship with the State's regulatory role are not unique to India, many of the specific questions which have emerged elsewhere remain absent there. As a case in point, consider debates surrounding religious parents' demands for exemptions from their States' educational regimes. Such claims had been made, for instance, in Yoder $v$ Wisconsin and Mozert v Hawkins in the United States. Theorists grappled with the morality of such exemptions, and the extent to which these were compatible with the core values of the liberal state. Another such example is provided by debates over claims by religious persons for funding from the State in the sphere of education. The central issue in the ensuing theoretical debate was whether it was permissible for the secular state to aid denominational schools financially or materially. ${ }^{50}$

Religious minority educational institutions in India have contested the degree of regulation the State may subject them to once it provides them with aid. However, the provision of state aid for religious minority educational institutions has not been contested. In fact, such educational institutions are even allowed to impart religious instruction insofar as they do not make attendance at such instruction mandatory. Thus, the notion that the Indian State may aid religious minority institutions, and may do so even if they impart religious instruction, is taken as uncontested in this debate even as 
it continues to be among the primary subjects of debate on religion and education in legal and theoretical debates elsewhere. Further, across landmark cases on this subject, religious minority educational institutions do not contest the State's authority to lay down a secular curriculum which they must follow. They have contested the degree of autonomy that may be curtailed by the State in administrative matters in exchange for recognition or aid, but no such claim has been made for autonomy in terms of curriculum.

That certain practices were left unquestioned is not unique to the Indian context. Tariq Modood and Varun Uberoi, for instance, point to a 'multicultural moment' in Britain in 2000, 'when non-Christian and non-Jewish faith schools received state funding, the Race Relations Amendment Act was passed and a policy of multiculturalism was relatively unquestioned' ${ }^{51}$ My aim here is not to mark out India as an exceptional case, but merely to emphasise the limits of much existing theoretical work on multiculturalism and education in addressing the specific constitutional debates that have emerged in India.

Let me emphasise an issue to which I later return in Section 5. The above presentation of the Court's jurisprudence has pertained only to one dimension of the cases examined. This first dimension has to do with the extent to which minority institutions ought to enjoy exemptions from the State's regulatory power. Given my interest in the conception of secularism at play in the Court's stance, I have focused only on this aspect of the jurisprudence here. However, questions about the selection of students and employees have also been posed under another dimension: the rights of private educational institutions, and the degree to which unaided institutions ought to have greater managerial autonomy relative to unaided ones. I return to this second dimension of these cases later in this article. Presently, let me summarise the underlying principles that have regulated the Court's response along both dimensions. On the one hand, it has ruled that minority educational institutions ought to have greater autonomy than their non-minority counterparts. The second principle underpinning the Court's jurisprudence has been that unaided educational institutions ought to have greater leeway from regulation than those aided by the State. This has resulted in a jurisprudence that gives greatest leeway to unaided minority institutions, while regulating aided non-minority institutions the most. 


\section{The Conceptual Purchase of Principled Distance}

I shall now argue that political secularism understood as principled distance better accounts for the Indian Supreme Court's stance on minority educational rights than competing alternatives outlined in Section 1. Before proceeding, I wish to emphasise that my concern here lies with secularism, understood as the relationship between the State and religion, rather than, say, an ethical ideal applicable to the lives of individual citizens. Further, most commentaries on the subject attempt to capture the relationship between the State and relationship in India. It is worth reiterating that my ambition here is narrower in scope. I am interested in how we ought to understand this relationship as far as educational rights are concerned. It is possible that the State's interaction with religion works differently in other domains, such as separate laws for marriage, or enforcement of non-discrimination caste laws. Although further work could fruitfully engage with how these different interactions of the State with religion hang together, there is value to isolating one domain for focused scrutiny.

By understanding secularism as compatible with acceptance of the claims of religious minorities, the principled distance approach serves as a more capacious conception as far as minority educational rights are concerned. In making sense of the Court's jurisprudence, it does better than an exclusivist approach, which insists that the State must erect a wall of separation with respect to religion. Any engagement with religion, even if it treats other religions equally, or takes place on terms compatible with the State's own principles, is impermissible under the exclusivist account of secularism. But instead of mandating such separation, the Court accepted claims by religious minorities for selecting their employees and students, as well as preferentially admitting students. It afforded them treatment that is distinctive relative to non-minorities. The Court justified this distinctive treatment by appealing to religious minorities' interests in educating children in a manner consistent with their ethos and religious tenets. On the exclusivist approach, the State ought to remain agnostic towards such interests, and not consider them in debates over public policy. In admitting such interests as justified grounds for special treatment, the Court's stance is better captured by Bhargava's suggestion that principled distance allows the State to engage with religion at the level of policy. 
Now one might argue that lexically ordered secularism helps account for the Court's stance on minority educational rights. After all, it admitted minorities' claims for autonomy in the sphere of education, but in a manner that is constrained by the State's claims for fair regulation. However, although the lexically ordered conception accounts for the fact of constraints, the principled distance approach does better in conceptualizing the nature of such constraints in India. In particular, it is better able to account for the intermediacy and contextualism of the Court's stance.

The lexically ordered approach posits a hierarchy between the exercise of religion and fundamental ideals that the State wishes to pursue. Principled distance eschews such hierarchies, and instead views the relationship between religion and the State as one subject to a balance of competing values at stake. This helps better capture the intermediacy which characterised the Court's position on minority educational rights. Rather than repudiating such rights altogether, the judiciary merely qualified them in the light of constraints it found legitimate. But the constraints themselves were qualified relative to the claim made by the State for greater intervention in minority institutions. Recall that the State had demanded that no places be reserved for students of particular communities in minority institutions, whereas the Court allowed for such reservations as long as some students from other communities were also admitted. While it rejected such institutions' claim to reserve all places for students of a particular community, it also qualified the State's claim that no reservation ought to be allowed. Similarly, it rejected the State's attempt to take over the selection of teachers in minority educational institutions. At the same time, it qualified minorities' claim to select their own teachers by insisting that this could be regulated through minimum educational qualifications, and standards of fairness. ${ }^{52}$ In doing so, it insisted on a balance of competing interests, rather than prioritising any one over others.

Further, the kind of intermediate arrangements established by the Court were often uneasy, an d not wholly specified. As such, it was characterised by the kind of contextual reasoning that Bhargava's principled distance approach emphasises. For instance, though it insisted on reconciling preferential admission for minorities with places for all other students, it suggested that the precise ratio ought to be contextually determined. Similarly, as I indicated in Section 3, the Court admitted that the reconciliation of minority educational rights with the State's claims for regulation did 
not allow for any rigid rules. Rather, the appropriate balance in each case would have to be determined in each case by weighing relevant social and individual interests involved. In allowing for such configurations, rather than a necessary subordination of claims of religion to secular constraints, principled distance provides a better account of the Court's stance.

Let me summarise the picture of secularism that emerges from our analysis. This picture is one where the State is allowed to engage with religion by exempting minorities from some of its regulatory power. However, this exemption is not absolute, and is constrained in significant ways when competing interests like academic excellence or the interests of teachers are at stake. The extent of engagement and the scope of its constraints are both somewhat indeterminate, allowing for a case-by-case approach towards these.

\section{The Second Dimension of Educational Rights Jurisprudence}

I have previously indicated that there is a second dimension to the cases explored in this article: the role of private enterprise in education. This is consistent with Nivedita Menon's suggestion that 'secularism in India cannot be understood in isolation from political economy imperatives' ${ }^{53}$ In its verdict in the Pai Case, the Court continued to hold that only minority educational institutions would have a right to admit students of their own community preferentially even if they drew aid from the State. Such a right was not available to aided non-minority educational institutions. ${ }^{54}$ Further, as in previous cases, this acceptance was qualified by the need to balance the right to admit students preferentially against the individual right to non-discrimination. However, with respect to matters pertaining to the selection and regulation of employees, and the procedure for selecting students, the Court held that all private educational institutions-minority as well as non-minority-were guaranteed a degree of autonomy. The degree of autonomy available to minority as well as non-minority educational institutions now depended on whether or not they drew aid from the state. ${ }^{55}$ In this sense, the Court's verdict can be seen as departing from its previous position that minorities were entitled to a special right to exemption from State regulation. ${ }^{56}$ 
In equating the administrative rights of minority educational institutions with that of non-minority educational institutions, the Pai judgment had the effect of making autonomy in matters pertaining to the selection and regulation of employees a function of educational institutions' status as private educational institutions. Viewing this through the first dimension emphasizes an equation of rights of minorities and nonminorities. On the other hand, the latter dimension allows us to understand it as an expansion of the administrative autonomy of all private educational institutions.

While further examination of the second dimension (private enterprise) is beyond the scope of this article, let me emphasise two ways in which it intersects with jurisprudence on the first dimension (rights of minorities). In what follows, I shed light on the bearers of rights under Article 30, as well as the scope of these rights vis-à-vis State regulation.

\section{(A) Managers as Bearers of Minority Educational Rights}

Recall that all minority educational institutions are private schools and colleges. As such, appealing for a greater leeway in the administration of institutions is to urge that the governing bodies of private educational institutions should not be fettered in their administrative function by governmental regulation. The exercisers of rights under Article 30 have not been individuals - such as parents - or communities, but the management of private aided or recognised minority educational institutions. As already pointed out, every private educational institution consists - at least on paperof a governing body, which is responsible for its administrative affairs. Though the right to freely administer religious minority educational institutions is claimed for the governing body, it does not mean that parents or communities are unaffected by such claims. For instance, the right of a governing body of a religious minority educational institution to formulate a policy of preferential admission to students from that minority's community makes it more likely that parents belonging to that community would be able to send their children to schools or colleges established by members of their community. However, this has not been claimed by parents as a matter of right, as the governing bodies of minority educational institutions have claimed they have, in formulating a policy of preferential admission. ${ }^{57}$ Thus, the debate on minority educational rights has been a debate about the rights available to the management - or 
governing body — of religious minority educational institutions. ${ }^{58}$ Expanding the rights of minority educational institutions is, among other things, a way of expanding the rights available to a particular set of private educational institutions.

\section{(B) The Wide Scope of Exemptions}

It is also worth highlighting a curious feature of the Court's jurisprudence on minority educational rights. While the Court has appealed to the need to protect the "minority character' of minority educational institutions, it is significant that some of the exemptions it has mandated have a wider scope. Consider, for instance, its permission to St. Stephen's College to conduct interviews for admission. It accepted the College's contention that it was entitled to exemption from the University's policy since, as a minority educational institution, it had the right to administer educational institution, which meant that its management was free to decide on the admission policy of its choice. The college did not claim that this policy was best suited for safeguarding its religious or cultural ethos. In fact, it emphasised that the interview was carried out by academicians and that this process provided an opportunity to get better insight into the academic strength of a candidate. The entire argument was made, and accepted by the Court, on the grounds that interviews were better indicators of academic merit. ${ }^{59}$ However, the College was able to successfully appeal to its rights as a minority institution to obtain such leeway, even though it was not defended as necessary to protect its minority character.

Similarly, in St. Xavier's, the Court held that the right to administer institutions included the right to select teachers based on 'their compatibility with the ideals and aims, aspirations and traditions of the institution'. ${ }^{60}$ It is unclear whether these ideals and aims that give minorities a right to exemption from State regulation over selection of teachers are those that pertain strictly to the protection of its culture, or any set of ideals and aims that might be professed even by non-minority educational institutions. Thus, for instance, the Court's stance is indifferent to whether a teacher is disciplined for blasphemy in a minority educational institution, or for criticizing the principal's policy on sport. In sum, minority educational institutions - which are privately run-have managed to appeal to their status as minority institutions to expand their managerial autonomy in ways that are untethered by any cultural purpose. That is, they have been 
successful in mobilising Article 30 to obtain exemptions from regulation even when these are not necessary to protect the minority character of such institutions.

Let me now summarise the argument so far. I have suggested that principled distance helps capture the Court's approach towards religious minority institutions in the cases examined here. But I have now also argued that engagement with religion is only one of two dimensions at play in these cases. Equally important to this debate has been the question of the State's relationship with private enterprise, and its expansion of autonomy available to privately managed educational institutions. Having said that, I now argue that the insight that the Court's engagement with religion is best captured by the principled distance approach helps respond to the debate over RTE and minority educational rights.

\section{Principled Distance and Access to Minority Schools}

In the Society case, the Court ruled that the RTE could be applied to minority schools aided by the State, but not to those which did not receive any aid. ${ }^{61}$ Although it distinguished between aided and unaided schools, this distinction was relevant only within the category of minority schools. The Court affirmed that all non-minority schools - aided and unaided — would be governed by the RTE. In Pramati, the Court dispensed with Society's insistence that the funding status of a minority institution was relevant for assessing whether or not it would have to implement the RTE. ${ }^{62}$ Instead, it ruled that the Right to Education Act would not apply to any minority schools. In both cases, the Supreme Court affirmed that the State could impose obligations upon private educational institutions. Nevertheless, minority educational institutions could be exempt from such regulation. In terms of the two dimensions discussed in this article, the Court's stance suggested that there could be regulation along the second (private schools) but not along the first (minority schools). Even when the Court's ruling in Society appealed to the second dimension as relevant, this was conditional on the first one coming into play. Given the salience of an institution's minority status, my argument that principled distance helps explain the State's engagement with religious minority institutions is relevant to our assessment of these two cases. ${ }^{63}$ 
Why were minority schools exempt from RTE? The Court argued that the application of RTE would entail that minority schools have a 'legal obligation to admit children belonging to weaker sections and disadvantaged groups in the neighbourhood who need not be children of the members of the minority community which has established the school' ${ }^{64}$ This was deemed impermissible since 'members of communities other than the minority community which has established the school cannot be forced upon a minority institution because that may destroy the minority character of the school' (emphasis mine) ${ }^{65}$ Managers of minority schools had an interest in ensuring that they could provide education consistent with the ethos of their community, as distinct from the wider societal ethos. This right was threatened by the application of RTE to minority schools. In sum, the Court was faced with two competing interests: the interest of poor parents and students in accessing education (N1) and the interest of minority educational institutions in retaining their 'minority character' (N2). The Court's position assumed that the latter could not be curtailed by reference to the former.

Recall that the Indian State is constitutionally prohibited from offering religious instruction in state-run schools. As such, only private educational institutions can offer religious education. If minority parents wish, then, for their children to obtain an education consistent with their community's ethos, private minority schools are their only avenue. However, this threatens to make education which is consistent with community's ethos a good available only to those who can afford it. If poor parents are unable to afford private minority schools, they must forgo an education of that sort. Indeed, the State is constitutionally permitted to offer financial aid to minority schools. But even this does not ensure access for poor minorities. This is because private schools, even when they receive financial aid from the State, are allowed to charge any fee from parents.

This is where principled distance can offer assistance. This conception involves permitting the State to engage with claims about religion, but in a way that balances competing interests involved. It allows us to insist that the State's relationship with religious minority rights factor in the interests of all stakeholders-including poor parents and their children-rather than just managers of minority schools. Principled 
distance can enable an insistence on the protection of $\mathrm{N} 2$ - the interest of minority schools in providing education consistent with their ethos. At the same time, it can suggest that the interests of the poor in accessing education (N1) be admitted insofar as they are compatible with N2. Note one way in which the two can be reconciled. Managers of minority schools can be permitted preferential admission policies for their community while being required to set aside some of those seats for poor members of their own community. In other words, one can demand affirmative action for poor minority students nested within prioritised admittance of religious minorities. Conceived in this way, the RTE can be made compatible with the maintenance of the 'minority culture' in minority educational institutions. Although this is not something that the Court explored, I believe it satisfies the principled distance approach's emphasis on balancing competing interests rather than treating them as a zero-sum game. ${ }^{66}$ It eschews drawing upon N1 to trump N2 by not insisting that minority students must admit poor students from outside their community. ${ }^{67}$

The approach I have highlighted here also renders the internal debate between Pramati and Society irrelevant. It insists that, like other aided and unaided schools, minority schools must also admit poor students whether or not these receive aid from the State. The underlying premise of the RTE is that the State is permitted to draw upon the resources of private schools even when they are not funded by the State. The objection to applying this principle to minority schools was that their distinctive character would be destroyed. If this were indeed the case, then the RTE's application to minority schools could have been opposed whether or not they drew financial aid from the State. Here, one might argue that balancing N1 and N2 entails applying RTE to aided minority schools but not to unaided schools, Thus, the argument might go, the Court's stance in Society represents a middle way of sorts. But since the proposal I have outlined in this section avoids impinging upon the character of minority schools, it renders the need for such balancing irrelevant.

\section{Conclusion}

The Indian Supreme Court's jurisprudence on minority educational rights can be described as a form of Bhargava's principled distance. The Court's stance exemplifies the kind of intermediacy and emphasis on contextual reasoning which are central to this 
conception. This approach is particularly significant insofar as conflicts like the ones discussed in this chapter are not unique to India. For instance, whether religious educational institutions can discriminate in favour of students from their own community is something other jurisdictions have also interrogated. The theoretical conception underpinning the Court's response, then, offers a resource worth exploring for contexts outside India as well. Further, Bhargava's conception enables us to respond to the two challenges mentioned at the beginning of this article. It addresses the Hindu right's criticism by suggesting educational rights for religious minorities are compatible with the concept of secularism. Such rights are grounded, as the Court argues, in the value of providing religious minorities a fair opportunity to protect and transmit their culture. On the other hand, our analysis also enables us to respond to concerns raised by proponents of the Right to Education. It enables us to argue that access to minority schools can be made compatible with Article 30 of the constitution.

${ }^{1}$ Throughout this article, I use 'State' where I refer to the nation-state, and 'state' in order to refer to provincial units in India.

${ }^{2}$ See S.R. Bommai vs. Union of India, MANU/SC/0444/1994: (1994) 3 SCC 1.

${ }^{3}$ Rajeev Bhargava, The Promise of India's Secular Democracy (New Delhi: Oxford University Press, 2010), pp. 84-87; Gurpreet Mahajan, Identities and Rights: Aspects of Liberal Democracy in India (New Delhi: Oxford University Press, 1998), pp. 80-86; Neera Chandhoke, 'Individual and Group Rights: A View from India,' in Zoya Hasan, E. Sridharan and R. Sudarshan (eds.), India's Living Constitution: Ideas, Practices, Controversies (London: Anthem Press, 2005), p. 209.

${ }^{4}$ Though these rights are guaranteed to religious and linguistic minorities, how a secular state can offer distinctive treatment to the former poses a significant theoretical puzzle. As such, this article's interest in the concept of secularism means I shall focus only on religious minorities. Six of these are recognized nationally: Muslims, Christians, Zoroastrians, Buddhists, Sikhs and Jainas.

${ }^{5}$ Tahir Mahmood, Politics of Minority Educational Institutions: Law and Reality in the Subcontinent (Gurgaon: ImprintOne, 2007), p. 142; Sukumar Muralidharan and S.K. Pande, 'Taking Hindutva to School,' Frontline 15, no. 23 (1998).

${ }^{6}$ Pramati Educational and Cultural Trust vs Union of India.

${ }^{7}$ Udit Bhatia, 'Competing Claims of Social Justice,' The Telegraph, 15 May 2014; Alok Prasanna Kumar, 'Right to Education: neither free nor compulsory,' The Hindu, 8 May 2014.

8 The Kerala Education bill, discussed below, constitutes an exception, where the State's regulation of religion was viewed as specifically motivated by enmity towards a religious minority community, rather than a function of routine administrative moves.

${ }^{9}$ Ronojoy Sen, Articles of Faith: Religion, Secularism, and the Indian Supreme Court (New Delhi: Oxford University Press, 2012), p. 95.

10 The Court's judgment in Pai was followed by a 2003 judgment in the Islamic Academy Case, which was intended to clarify the decision in the former. The 2003 
judgment, however, only furthered the lack of clarity, resulting in a 2005 judgment in the Inamdar Case that sought to clarify the judiciary's stance in the Pai judgment yet again.

${ }^{11}$ See judgment of the Supreme Court of South Dakota in Richard Collins v Faith School District, No. 19959 of 1998.

${ }^{12}$ See judgment of the Supreme Court of the United Kingdom, $R$ v Governing Body of $J F S$ and the Admissions Appeal Panel of JFS and others and $R \vee$ Governing Body of JFS and the Admissions Appeal Panel of JFS and others (United Synagogue), Michaelmas Term (2009) UKSC 15, Decided on 16 December, 2009.

${ }^{13}$ Bhargava, India's Secular Democracy, op. cit., Ref. 3, p. 74.

${ }^{14}$ Ibid., p. 75.

${ }^{15}$ Ibid., p. 81.

${ }^{16}$ Ibid., p. 94.

${ }^{17}$ Ibid., p. 95.

${ }^{18}$ Alternatively, exclusivism might also involve unilateral separation, where the church and church-based religions must be excluded from the State at the levels of ends, institutions and policy, but the State retains the power to interfere in church-based religions at the third level. Bhargava identifies mutual exclusion as the idealised American model, whereas the French approach permits unilateral, mostly negative engagement of the State with religion. See his 'Is European Secularism Secular Enough,' in Jean L. Cohen and Cécile Laborde, eds., Religion, Secularism and Constitutional Democracy (New York: Columbia University Press, 2016), 165-167.

${ }_{19}$ Akeel Bilgrami, Secularism, Identity and Enchantment (Cambridge, Mass and London: Harvard University Press, 2014), pp. 13-14.

${ }^{20}$ Ibid., p. 12.

${ }^{21}$ Ibid., p. 31.

${ }^{22}$ Bhargava, India's Secular Democracy, op. cit., Ref. 3, p. 94.

${ }^{23}$ Stephen Macedo, 'Liberal Civic Education and Religious Fundamentalism: The Case of God v. John Rawls?,' Ethics 105 no. 3 (1995), 468-496; Jonathan Quong, Liberalism without Perfection (Oxford: Oxford University Press, 2010 ), pp. 256-89.

${ }^{24}$ Susan Moller Okin, 'Is Multiculturalism Bad for Women?,. in Joshua Cohen, Matthew Howard, and Martha C. Nussbaum, eds., Is Multiculturalism Bad for Women? (Princeton: Princeton University Press, 1999), pp. 7-24; Brian Barry, Culture and Equality: An Egalitarian Critique of Multiculturalism (Cambridge: Polity Press, 2001). Although I cannot press this point further, it is possible to view Charles Taylor as a proponent of the lexically ordered approach despite Bilgrami's attempt to distinguish between his own approach and Taylor's. Taylor insists that the State's engagement with religion ought to be regulated by principles like human rights, equality, the rule of law, democracy. He argues that these are the very bases for his principles of secularism, and, therefore, must not be given up in the name of free exercise of religion. This allows him, for instance, to insist on the liberal ideal of freedom of expression to take precedence over claims of religious groups to ban material considered blasphemous. See Jocelyn Maclure and Charles Taylor, Secularism and Freedom of Conscience (Cambridge, Mass. and London: Harvard University Press, 2011), p. 1078.

${ }^{25}$ T.N. Madan, 'Secularism in its Place,' in Rajeev Bhargava, ed., Secularism and its Critics (New Delhi: Oxford University Press, 1998), pp. 297-320. Also see Ashis Nandy, 'The Politics of Secularism and the Recovery of Religious Tolerance' in ibid., pp. 321-344

${ }^{26}$ Bilgrami, Secularism, Identity and Enchantment, op. cit., Ref. 19, pp. 48-50. 
${ }^{27}$ Gary Jeffrey Jacobsohn, The Wheel of Law: India's Secularism in Comparative Constitutional Context (New Delhi: Oxford University Press, 2003).

28 Ibid., p. 278.

${ }^{29}$ Gyanendra Pandey, Remembering Partition: Violence, Nationalism and History in India (Cambridge: Cambridge University Press, 2001), p. 2.

${ }^{30}$ Rochana Bajpai, Debating Difference (New Delhi: Oxford University Press, 2011).

31 Shefali Jha, 'Rights versus Representation - Defending Minority Interests in the Constituent Assembly,' in Rajeev Bhargava, ed., Politics and Ethics of the Indian Constitution (New Delhi: Oxford University Press, 2008), pp. 339-353.

${ }^{32} R e$ : The Kerala Education Bill vs. Unknown, MANU/SC/0029/1958: [1959] 1 SCR 995; The Ahmedabad St. Xavier's College vs. State of Gujarat, MANU/SC/0088/1974: [1975] 1 SCR 173; St. Stephen's College vs. University of Delhi, MANU/SC/0319/1992: AIR 1992 SC 1630; TMA Pai Foundation vs. State of Karnataka, MANU/ SC/1050/2002: (2002) 8 SCC 481.

${ }^{33}$ See PA Inamdar vs. State of Maharashtra, MANU/SC/0482/2005: 2005 (6) SCC 537, para 1.

34 The Court's judgment does not list the petitioners. The title of the case names TMA Pai Foundation, a trust for the Konkani speaking community, which forms a linguistic minority in the Indian state of Karnataka. Another petitioner in this case was the Islamic Academy of Education about which no further information is available.

${ }^{35}$ In practice, however, most private educational institutions do run as for-profit organisations, mostly through illicit means like 'donations' in lieu of admission See Patricia Jeffery, Roger Jeffery and Craig Jeffrey, 'Islamization, Gentrification and Domestication: “A girls' Islamic Course" and Rural Muslims in Western Uttar Pradesh,' Modern Asian Studies 38, no. 1 (2004), 35.

${ }^{36}$ Ibid.

37 Article 28(3) of the Indian Constitution prohibits mandatory religious instruction in educational institutions either recognised or aided by the State.

38 Various state governments in India's quasi-federal structure have adopted their own guidelines on how to identify which institutions qualify for 'minority' status. These are often at odds with national guidelines framed by a statutory body established by an act of Parliament in 2004. For instance, some states have issued guidelines that a minority educational institution must have a minimum percentage of students from the particular minority community it purportedly serves. On the other hand, national guidelines suggest that minority status is to be awarded where the management consists largely of persons belonging to a particular minority religious denomination. It is also unclear how many states in India even have a definite understanding of what constitutes a minority educational institution. See Jayna Kothari and Aparna Ravi, 'A Battle of Rights: The Right to Education of Children versus Rights of Minority Schools,' Oxford University Commonwealth Law Journal 16, no. 2 (2016), 202-203.

39 Stephen's, paras. 21-22. St. Stephen's College is a constituent college of the University of Delhi, a State-run establishment. As such, the curriculum and examinations are governed by the norms of the University. Further, like all other colleges in the University — which include primarily non-minority institutions - St. Stephen's College can only recruit teachers who fulfil minimum qualifications specified by the University Grants Commission, India's regulatory body in higher education.

40 Ibid., paras. 68-72.

${ }^{41}$ This is an interesting understanding of non-discrimination, since it continues to award a greater probability of admission to some students on the basis of their religion, while reducing opportunities available to others. It is helpful to understand non-discrimination in this context as non-exclusion, which 
allows for justifiable differences in the opportunities distributed between members of various groups, while insisting on the availability of opportunity for all persons. Defending this somewhat unusual formulation as a plausible interpretation of the principle of non-discrimination is beyond the scope of this article.

${ }^{42}$ Pai, para. 151.

${ }^{43}$ Xavier's, paras. 17, 90; Stephen's, paras. 62-65.

${ }^{44}$ Xavier's, para. 106, Pai, paras. 137, 162(G).

45 Jean L. Cohen, 'Rethinking Political Secularism' in Cohen and Laborde, Religion, Secularism and Constitutional Democracy, op. cit., Ref. 18, pp. 131-132.

${ }^{46}$ Kerala Education Bill, para. 47.

${ }^{47}$ Xavier's, para. 36. Also see ibid., paras. 109, 188.

${ }^{48}$ Stephen's, para. 100; Pai, paras. 138, 230.

${ }^{49}$ Ibid. 102; Xavier's, para. 77.

${ }^{50}$ Eamonn Callan, 'Discrimination and Religious Schooling', in Will Kymlicka and Wayne Norman, eds., Citizenship in Diverse Societies (Oxford: Oxford University Press), pp. 45-67; Ian MacMullen, Faith in Schools? Autonomy, Citizenship, and Religious Education in the Liberal State (Princeton: Princeton University Press, 2007); Bryan T. McGraw, 'Liberal Multiculturalism and Confessional Religious Schooling,' Political Studies 63, no. 5 (2014), 1087-1102;

${ }^{51}$ Varun Uberoi and Tariq Modood, 'Inclusive Britishness: A Multiculturalist Advance,' Political Studies 61, no. 1 (2013): 2.

${ }^{52}$ See Refs. 43 and 44 above.

${ }^{53}$ Nivedita Menon, 'Living with Secularism,' in Anuradha Dingwaney Needham and Rajeswari Sunder Rajan, eds., The Crisis of Secularism in India, (Durham and London: Duke University Press, 2007), p. 131.

54 This was later affirmed in Indian Medical Association vs. Union of India, 20117 SCC 179.

${ }^{55}$ I have discussed the varying degrees of autonomy available to aided and unaided educational institutions in the second section of this article.

${ }^{56}$ For further discussion of this dimension in Pai, and the Court's wider engagement with private educational institutions, see Devesh Kapur and Pratap Bhanu Mehta, Indian Higher Education Reform: From Half-Baked Socialism to Half-Baked Capitalism, Working Paper No. 8, (Center for International Development, Harvard, 2004).

${ }^{57}$ It is important to note that even the decision to go to Court ultimately rests with the Governing body. Individual members of the institution, such as its Principal or its staff, cannot initiate judicial proceedings on behalf of that institution.

${ }^{58}$ While the right to administer is claimed for the governing body, I am mindful of the suggestion that these only exist on paper in many educational institutions. See Jeffrey et al., Islamization, Gentrification and Domestication, op. cit., Ref. 35. As such, I prefer to use the term 'management' which allows for the possibility that educational institutions are effectively administered only by individuals rather than a governing body.

${ }^{59}$ Stephen's, paras. 70-71.

${ }^{60}$ Xavier's, para. 19.

${ }^{61}$ Society for Un-Aided Private Schools of Rajasthan vs. Union of India, MANU/SC/0311/2012: (2012) 6 SCC 1 . 
62 Pramati Educational and Cultural Trust vs. Union of India, MANU/SC/0419/2014: (2014) 8 SCC 1.

${ }^{63}$ I thank an anonymous reviewer for the Journal of Political Ideologies for urging me to clarify this point.

${ }^{64}$ Ibid., para. 46.

${ }^{65}$ Ibid. The Court also made the same argument in Society, para. 19

${ }^{66}$ Pratap Bhanu Mehta has suggested a similar reconciliation is his comments on the Pramati case. See his article, 'Classroom Struggle,' The Indian Express, 18 April 2012. ${ }^{67}$ Once the applicability of the RTE to minority schools is settled, a further question about the scope of such application would remain. Consistent with the Court's emphasis on context, one might argue for a contextual determination, rather than fixed percentage, of the proportion of poor students to be admitted in minority schools. I cannot pursue this here, and have instead chosen to focus on the prior question of the RTE's applicability. 